\title{
インスリン非依存型糖尿病におけるプロブコール長期投与の HDL-コレステロールへの影響
}

$\begin{array}{llllllll}\text { 河 原 玲子* } & \text { 柴 田 尚 美* 柴 崎 智 美* } & \text { 雨 宮 禎 子* } \\ \text { 戸 谷 理英子* 宮 前 至 博* 笹 本 和 男* } & \text { 大 森 安 恵* }\end{array}$

\section{I. はじめに}

プロブコールのコレステロール (TC) 低下作用は, LDL-コレステロール (LDL-C) のみならず， HDL-コレ ステロール (HDL-C) においてもみられるために使用上 問題とされてきた.一方インスリン非依存型糖尿病 (NIDDM) では高脂血症と低 HDL-C 血症が合併しやす い1,2). したがって NIDDM にプロブコールを使用する 場合には，HDL-C の低下がより増強される懸念がある。 そこでこの実態を明らかにするために，NIDDM で高 TC 血症を有するものにプロブコールを長期間使用して， HDL-C の変動を中心に検討した.

\section{II. 対象と方法}

対象は当センターに通院中の NIDDM で高 TC 血症 を合併した男性 29 名, 女性 91 名, 計 120 名である. 平均年齢 $62.5 \pm 9.0$ 歳 (30 83 歳), Body Mass Index (BMI) $23.1 \pm 3.8$ (15.1 36.7). 糖尿病の治療は食事療法 25 例, 経口血糖降下薬 63 例, インスリン 32 例であった. 糖尿病性網膜症を有するもの 63 例のうち増殖網膜症 8 例, 糖尿病性腎症 14 例のうち 2 例が透析中であった. 既往に脳血栓を有するもの 8 例, 心筋梗塞を有するもの 13 例が含まれた. 家族性高コレステロール血症と考えら れるものは対象より除外した.

高 TC 血症の判定は, 血糖コントロールが安定してい るも，な扮血中 TC $240 \mathrm{mg} / \mathrm{d} l$ 以上が続くものとした. 他の抗脂血剂を使用中のものは, 1 か月以上中止後のコ レステロール值で判定した. プロブコールの投与は, 単

\footnotetext{
* 東京女子医科大学糖尿病センター 原稿受取日：1993 年 1 月 29 日

採用決定日：1993 年 3 月 9 日
}

独使用 (以下単独群) とパンテチンと併用 (以下併用群) の 2 群に分けた。単独群 88 名は，プロブコール $250 \mathrm{mg}$ を 1 日 1 回投与 29 名と, $500 \mathrm{mg}$ を 1 日 2 回分割投与 59 名であった。併用群 32 名は, プロブコール $250 \mathrm{mg}$ とパンテチン $200 \mathrm{mg}$ を 1 日 1 回投与 2 名と, プロブコ ール $500 \mathrm{mg}$ とパンテチン $400 \mathrm{mg}$ を 1 日 2 回分割投与 30 名であった.

採血時間は原則として早朝空腹時とした（以下食前群 $\mathrm{n}=55$ )．しかしやむを得ず食後に来院する者では，朝食 後または昼食後 2 時間以降に採血した（以下食後群 $n=$ 65). 各人の採血時間は一定にした. プロブコール使用前 と使用後 1 年から 5 年まで, 1 年ごとの血中脂質の測定 值を用いた. LDL-C は Friedewald の式より算出した. 統 計処理は濃度の経年比較を paired t-test, 変化量と変化 率の比較を Wilcoxon Signed-rank test, 群間比較を t-test および Wilcoxon 2 sample test で行った.

\section{III. 成 績}

\section{1）単独群と併用群における臨床像の比較}

プロブコール単独群とパンテチンとの併用群における 治療開始前の臨床像を示した (Table 1). 単独群では女性 が多く含まれたが, 年齢, BMI, へモグロビン $\mathrm{A}_{1 \mathrm{C}}$, 飲 酒および契煙率は両群間に差がなかった．また単独群で インスリン治療と網膜症を有するものが多かった。

\section{2）プロブコール 5 年投与における TC の変動}

$\mathrm{TC}$ に扔けるプロブコール投与 5 年間の変動をみた (Table 2). 単独群, 併用群ともに血中 TC 濃度は, プロ ブコール投与 1 年後より有意に低下し， 5 年間持続した。 両群間に有意差はなかった. 1 年後の平均低下量は 45〜 $54 \mathrm{mg} / \mathrm{d} l$ で，低下率は約 $17 \%$ であった。 なお食前群と 食後群でも有意差はみられなかった。 
Table 1 Clinical findings of the non-insulin dependent diabetic patients with hypercholesterolemia at entry

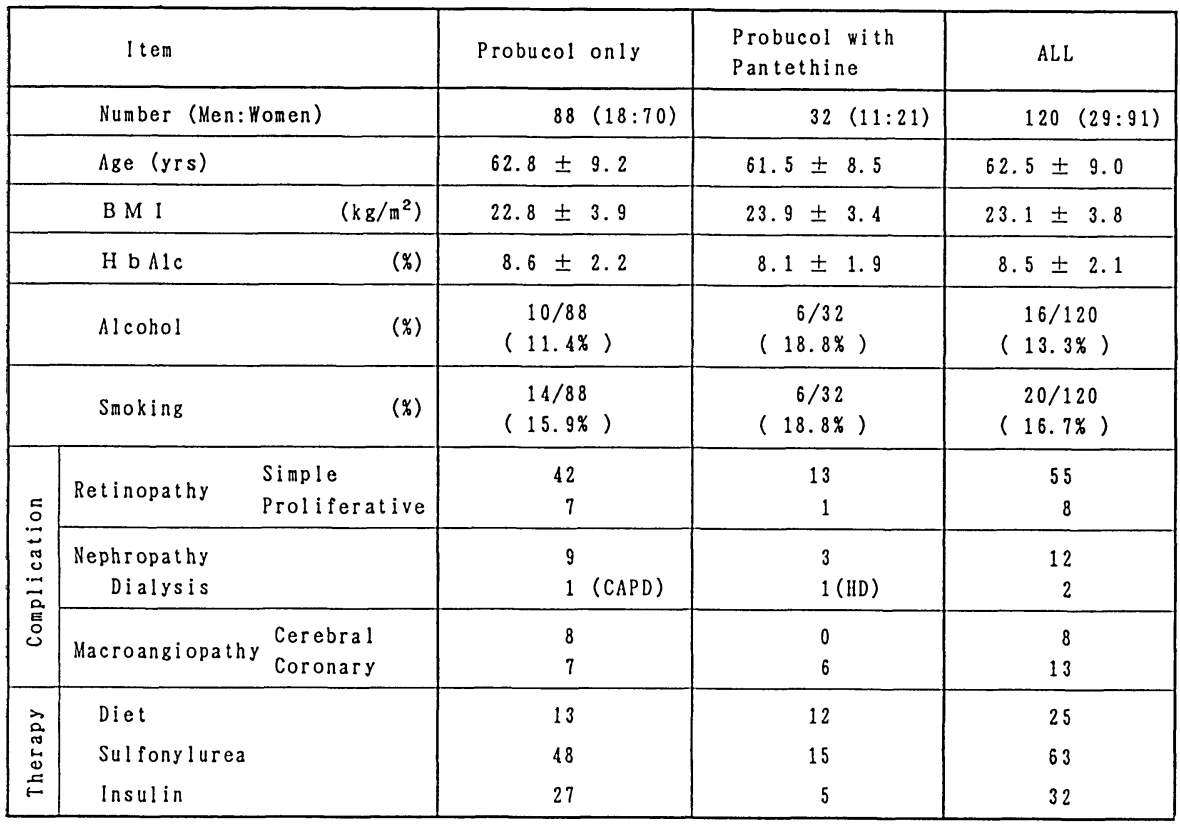

BMI : Body Mass Index

Mean \pm S. D.

CAPD. Continuous ambulatory peritoneal dialysis

HD : hemodialysis

Table 2 Changes of the total cholesterol level during treatment for 5 years with probucol alone and probucol plus pantethine

\begin{tabular}{|c|c|c|c|c|c|c|c|c|c|c|c|c|}
\hline & \multirow[b]{2}{*}{ yrs } & \multicolumn{4}{|c|}{ Probucol only } & \multicolumn{4}{|c|}{ Probucol with Pantethine } & \multicolumn{3}{|c|}{$\begin{array}{c}\text { Probucol only } \\
\text { VS } \\
\text { Probucol with Pante thine }\end{array}$} \\
\hline & & n & $\begin{array}{l}\text { Concentrations } \\
(\mathrm{mg} / \mathrm{dl})\end{array}$ & $\begin{array}{l}\text { Volume of change } \\
(\mathrm{mg} / \mathrm{dl})\end{array}$ & $\begin{array}{l}\text { Rate of change } \\
\text { (y) }\end{array}$ & $\mathrm{n}$ & $\begin{array}{l}\text { Concentrations } \\
(\mathrm{mg} / \mathrm{dl})\end{array}$ & $\begin{array}{l}\text { Volume of change } \\
(\mathrm{mg} / \mathrm{dl})\end{array}$ & $\begin{array}{l}\text { Rate of change } \\
\text { (y) }\end{array}$ & Conc. & $\begin{array}{l}\text { Vol. of } \\
\text { change }\end{array}$ & $\begin{array}{r}\text { Rate of } \\
\text { change }\end{array}$ \\
\hline Fasting & $\begin{array}{l}0 \\
1 \\
2 \\
3 \\
4 \\
5\end{array}$ & $\begin{array}{r}31 \\
31 \\
24 \\
14 \\
8 \\
8\end{array}$ & $\begin{array}{l}270.16 \pm 5.22 \\
225.61 \pm 503 * * * \\
220.96 \pm 6.38 * * * \\
219.57 \pm 7.26 * * * \\
210.50 \pm 11.74 * * \\
19967 \pm 1162 * *\end{array}$ & 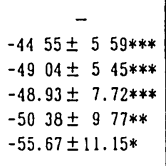 & 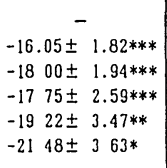 & $\begin{array}{r}24 \\
17 \\
9\end{array}$ & $\begin{array}{l}284.87 \pm 9.28 \\
229.76 \pm 8 \quad 80 * * \\
21967 \pm 11.63 * *\end{array}$ & $\begin{array}{c}- \\
-47.76 \pm 12 \quad 24 * * \\
-79 \quad 22 \pm 19.21 * *\end{array}$ & $\begin{array}{cc} & - \\
-15 & 35 \pm 4.77 * * \\
-25 & 06 \pm 5.10 * *\end{array}$ & N.S. & N S. & N.S. \\
\hline $\begin{array}{l}\text { Post } \\
\text { prandial }\end{array}$ & $\begin{array}{l}0 \\
1 \\
2 \\
3 \\
4 \\
5\end{array}$ & $\begin{array}{r}57 \\
54 \\
45 \\
18 \\
11 \\
6\end{array}$ & $\begin{array}{l}273.46 \pm 4.82 \\
225.56 \pm 4.55 * * * \\
225.56 \pm 4.61 * * * \\
211.83 \pm 821 * * * \\
227.91 \pm 1034 * * * \\
209.33 \pm 17.90 * *\end{array}$ & 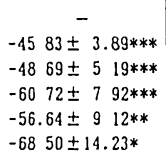 & \begin{tabular}{l}
\multicolumn{1}{c}{-} \\
$-16.66 \pm 1.36 * * *$ \\
$-17.10 \pm 1.56 * * *$ \\
$-2177 \pm 2.61 * * *$ \\
$-19.71 \pm 2.99 * *$ \\
$-24.58 \pm 4.32 *$
\end{tabular} & $\begin{array}{l}8 \\
6 \\
7 \\
5 \\
5 \\
2\end{array}$ & $\begin{array}{l}309.87 \pm 17.46 \\
244.67 \pm 17.21 * \\
23671 \pm 1269 * \\
239.00 \pm 568 * * * \\
23580 \pm 1148 * * \\
235.50 \pm 14.50\end{array}$ & \begin{tabular}{l}
\multicolumn{1}{c}{-} \\
$-70.50 \pm 24.16$ \\
$-78.29 \pm 27.33 *$ \\
$-6260 \pm 6.38$ \\
$-65.80 \pm 12.63$ \\
$-8300 \pm 12.00$
\end{tabular} & \begin{tabular}{l}
\multicolumn{1}{c}{-} \\
$-21.08 \pm 6.91$ \\
$-22.97 \pm 5.95 *$ \\
$-20.59 \pm 1.53$ \\
$-21.60 \pm 3.83$ \\
$-2609 \pm 337$
\end{tabular} & N.S. & N.S. & N.S. \\
\hline All & $\begin{array}{l}0 \\
1 \\
2 \\
3 \\
4 \\
5\end{array}$ & $\begin{array}{l}88 \\
85 \\
69 \\
32 \\
19 \\
12\end{array}$ & $\begin{array}{l}272.30 \pm 3.61 \\
225.58 \pm 3.40 * * * \\
223.96 \pm 3.72 * * * \\
215.22 \pm 5.56 * * * \\
220.58 \pm 7.81 * * * \\
20450 \pm 10.28 * * *\end{array}$ & $\begin{array}{c}- \\
-4536 \pm 3.18 * * * \\
-48.81 \pm 3.86 * * * \\
-55.56 \pm 560 * * * \\
-5400 \pm 6.55 * * * \\
-6208 \pm 8.83 * * *\end{array}$ & 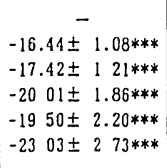 & $\begin{array}{r}32 \\
23 \\
16 \\
6 \\
5 \\
2\end{array}$ & $\begin{array}{l}291.12 \pm 8.30 \\
233.65 \pm 7.82 * * * \\
227.12 \pm 8.60 * * * \\
236.33 \pm 535 * * * \\
235.80 \pm 11.48 * * \\
23550 \pm 1450\end{array}$ & $\begin{array}{l}- \\
-53.70 \pm 10.94 * * * \\
-7881 \pm 15.55 * * * \\
-59.17 \pm 6.24 * \\
-65.80 \pm 12.63 \\
-83.00 \pm 12.00\end{array}$ & \begin{tabular}{l}
\multicolumn{1}{c|}{-} \\
$-16.85 \pm 3.92 * * *$ \\
$-24.14 \pm 3.75 * * *$ \\
$-19.80 \pm 1.48 *$ \\
$-21.60 \pm 3.83$ \\
$-2609 \pm 3.97$
\end{tabular} & N.S & N.S. & N S. \\
\hline
\end{tabular}


Table 3 Changes of the LDL-cholesterol level during treatment for 5 years with probucol alone and probucol plus pantethine

\begin{tabular}{|c|c|c|c|c|c|c|c|c|c|c|c|c|}
\hline & \multirow[b]{2}{*}{ yrs } & \multicolumn{4}{|c|}{ Probucol only } & \multicolumn{4}{|c|}{ Probucol with Pantethine } & \multicolumn{3}{|c|}{$\begin{array}{c}\text { Probucol only } \\
\text { vS } \\
\text { Probucol with Pantethine }\end{array}$} \\
\hline & & $\pi$ & $\begin{array}{l}\text { Concentrations } \\
(\mathrm{mg} / \mathrm{d} \mathrm{l})\end{array}$ & $\begin{array}{l}\text { Volume of change } \\
(\mathrm{mg} / \mathrm{dl})\end{array}$ & $\begin{array}{l}\text { Rate of change } \\
(\%)\end{array}$ & $n$ & $\begin{array}{l}\text { Concentrations } \\
(\mathrm{mg} / \mathrm{dl})\end{array}$ & $\begin{array}{l}\text { Volume of change } \\
(\mathrm{mg} / \mathrm{dl})\end{array}$ & $\begin{array}{l}\text { Rate of change } \\
(\boldsymbol{y})\end{array}$ & Conc. & $\begin{array}{l}\text { Vol. of } \\
\text { change }\end{array}$ & $\begin{array}{l}\text { Rate of } \\
\text { change }\end{array}$ \\
\hline Fasting & $\begin{array}{l}0 \\
1 \\
2 \\
3 \\
4 \\
5\end{array}$ & $\begin{array}{r}31 \\
31 \\
24 \\
14 \\
8 \\
6\end{array}$ & $\begin{array}{l}180.55 \pm 5.31 \\
14658 \pm 485 * * * \\
14287 \pm 5.50 * * * \\
138.11 \pm 7.26 * * \\
13830 \pm 1106 * * \\
125.82 \pm 18.45 *\end{array}$ & $\begin{array}{c}- \\
-3396 \pm 4.67 * * * \\
-37.70 \pm 5.08 * * * \\
-43.77 \pm 10 \quad 53 * * * \\
-4338 \pm 11.92 * * \\
-54.98 \pm 14.76 *\end{array}$ & 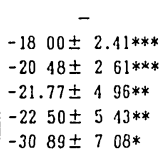 & $\begin{array}{r}24 \\
17 \\
9\end{array}$ & $\begin{array}{l}18509 \pm 885 \\
15358 \pm 789 * \\
136 \quad 64 \pm 14.47 * *\end{array}$ & $\begin{array}{cc} & - \\
-30 & 01 \pm 11.27 * \\
-54 & 34 \pm 13 \quad 81 * *\end{array}$ & $\begin{array}{l}\stackrel{-}{-} \\
-11.70 \pm 6.99 * \\
-27.79 \pm 7.27 * *\end{array}$ & N S. & N.S. & N.S. \\
\hline $\begin{array}{l}\text { Post } \\
\text { prandial }\end{array}$ & $\begin{array}{l}0 \\
1 \\
2 \\
3 \\
4 \\
5\end{array}$ & $\begin{array}{r}57 \\
54 \\
45 \\
18 \\
11 \\
11 \\
6\end{array}$ & $\begin{array}{l}172.72 \pm 428 \\
143.01 \pm 4.60 * * * \\
143.46 \pm 454 * * * \\
129.53 \pm 8847 * * \\
141.38 \pm 1131 * * \\
12883 \pm 1932 *\end{array}$ & 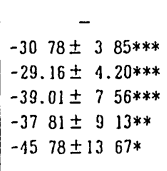 & \begin{tabular}{lll}
\multicolumn{4}{c}{-} \\
-17 & $25 \pm 2$ & $06 * * *$ \\
-16 & $26 \pm 2$ & $25 * * *$ \\
$-22.67 \pm 3$ & $70 * * *$ \\
-21 & $22 \pm 4$ & $90 * *$ \\
-26 & $54 \pm 6$ & $18 *$
\end{tabular} & $\begin{array}{l}8 \\
6 \\
7 \\
4 \\
5 \\
2\end{array}$ & 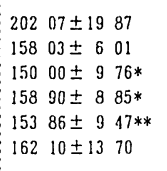 & $\begin{array}{c}- \\
-49.63 \pm 2881 \\
-6457 \pm 25 \quad 54 * \\
-41.05 \pm 7.61 \\
-42.38 \pm 8 \quad 12 \\
-44 \quad 10 \pm 20.70\end{array}$ & $\begin{array}{l}- \\
-15 \quad 70 \pm 14.93 \\
-26.56 \pm 7.93 * \\
-20.35 \pm 3.24 \\
-21.51 \pm 4.03 \\
-2107 \pm 932\end{array}$ & N.S. & N.S. & N.S. \\
\hline$A ! 1$ & $\begin{array}{l}0 \\
1 \\
2 \\
3 \\
1 \\
5\end{array}$ & $\begin{array}{l}88 \\
85 \\
69 \\
32 \\
19 \\
12\end{array}$ & 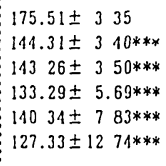 & 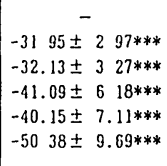 & 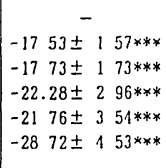 & $\begin{array}{r}32 \\
2.3 \\
16 \\
5 \\
5 \\
2\end{array}$ & $\begin{array}{lll}189 & 34 \pm 8 & 22 \\
159 & 17 \pm 5 & 97 * * \\
142 & 49 \pm 9 & 08 * * * \\
153 & 96 \pm 8 & 45 * * \\
153 & 86 \pm 9.47 * * \\
162.10 \pm 13 & 70\end{array}$ & \begin{tabular}{|ccc} 
& - \\
-35 & $13 \pm 10$ & $99 * *$ \\
-58 & $82 \pm 13$ & $16 * * *$ \\
-38 & $64 \pm 6.37$ \\
$-42.38 \pm 8$ & 12 \\
-44 & $10 \pm 20$ & 70
\end{tabular} & $\begin{array}{l}\quad- \\
-12.74 \pm 630 * \\
-27.25 \pm 518 * * * \\
-1984 \pm 2.57 \\
-21.51 \pm 4.03 \\
-21.07 \pm 3.32\end{array}$ & $\begin{array}{l}\text { N.S. } \\
* \\
\text { N.S. }\end{array}$ & N.S & NS \\
\hline
\end{tabular}

The level of each years vs 0 point $*: P<0 \quad 05 * * P<001 * * * P<0001$

Table 4 Changes of the HDL-cholesterol level during treatment for 5 years with probucol alone and probucol plus pantethine

\begin{tabular}{|c|c|c|c|c|c|c|c|c|c|c|c|c|}
\hline & \multirow[b]{2}{*}{ yrs } & \multicolumn{4}{|c|}{ Probucol only } & \multicolumn{4}{|c|}{ Probucol with Pantethine } & \multicolumn{3}{|c|}{$\begin{array}{l}\text { Probucol only } \\
\text { VS } \\
\text { Probucol with Pantethine }\end{array}$} \\
\hline & & $n$ & $\begin{array}{l}\text { Concentrations } \\
(\mathrm{mg} / \mathrm{dl})\end{array}$ & $\begin{array}{c}\text { Volume of change } \\
(\mathrm{mg} / \mathrm{dl})\end{array}$ & $\begin{array}{l}\text { Rate of change } \\
\text { (f) }\end{array}$ & $n$ & $\begin{array}{l}\text { Concentrations } \\
(\mathrm{mg} / \mathrm{d} \mathrm{l})\end{array}$ & $\begin{array}{l}\text { Volume of change } \\
(\mathrm{mg} / \mathrm{dl})\end{array}$ & $\begin{array}{l}\text { Rate of change } \\
(y)\end{array}$ & Conc. & $\begin{array}{l}\text { Vol of } \\
\text { change }\end{array}$ & $\begin{array}{l}\text { Rate of } \\
\text { change }\end{array}$ \\
\hline Fasting & $\begin{array}{l}0 \\
1 \\
2 \\
3 \\
4 \\
5\end{array}$ & $\begin{array}{r}31 \\
31 \\
21 \\
14 \\
8 \\
6\end{array}$ & $\begin{array}{llll}57 & 55 \pm & 3 & 27 \\
48 & 58 \pm & 2 & 46 * * * \\
47.71 \pm & 2 & 94 * * * \\
49 & 43 \pm & 4 & 31 \\
43.75 \pm & 3.57 \\
39 & 33 \pm & 6 & 73\end{array}$ & $\begin{array}{c}- \\
-8.97 \pm 2 \\
-1013 \pm 2.17 * * * \\
-8.14 \pm 404 \\
0.00 \pm 3 \\
-233 \pm 295\end{array}$ & \begin{tabular}{rlll}
\multicolumn{4}{c}{-} \\
-12 & $36 \pm 3$ & $36 * * *$ \\
-14 & $53 \pm 4$ & $09 * *$ \\
-8 & $22 \pm$ & 6 & 94 \\
5 & $78 \pm 9$ & 45 \\
$-4.06 \pm 7.40$
\end{tabular} & $\begin{array}{r}24 \\
17 \\
9\end{array}$ & $\begin{array}{ll}49 & 25 \pm 277 \\
42 & 41 \pm 1.90 * \\
44 & 22 \pm 527 *\end{array}$ & $\begin{array}{c}- \\
-782 \pm 2.80 * \\
-744 \pm 257 *\end{array}$ & 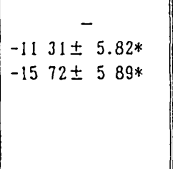 & N S & N S & N S \\
\hline $\begin{array}{l}\text { Post } \\
\text { prandial }\end{array}$ & $\begin{array}{l}0 \\
1 \\
2 \\
3 \\
4 \\
5\end{array}$ & $\begin{array}{r}57 \\
54 \\
45 \\
18 \\
11 \\
6\end{array}$ & $\begin{array}{lll}55 & 88 \pm 2.27 \\
46.74 \pm & 1.87 * * * \\
45.07 \pm 2 & 25 * * * \\
44 & 78 \pm 2.82 * * \\
46 & 45 \pm & 4.38 * \\
47 & 33 \pm 6 & 52\end{array}$ & $\begin{array}{c}- \\
-9.55 \pm 1.27 * * * \\
-10.11 \pm 1.84 * * * \\
-9.44 \pm 2.76 * * \\
-8.91 \pm 3.17 * \\
-10.00 \pm 5.35\end{array}$ & $\begin{array}{l}- \\
-1534 \pm 217 * * * \\
-16.29 \pm 3.23 * * * \\
-12.82 \pm 3.90 * * \\
-13.12 \pm 4.06 * \\
-963 \pm 10.63\end{array}$ & $\begin{array}{l}8 \\
6 \\
7 \\
4 \\
5 \\
2\end{array}$ & 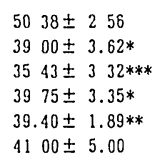 & $\begin{array}{cc} & - \\
-9 & 67 \pm 2.75 \\
-15.57 \pm 2.57 * \\
-11 & 75 \pm 3.38 \\
-13 & 80 \pm 2.82 \\
-10.50 \pm 3 & 50\end{array}$ & \begin{tabular}{l}
\multicolumn{1}{c}{-} \\
$-1990 \pm 562$ \\
$-30.78 \pm 4.78 *$ \\
$-22.56 \pm 6.29$ \\
$-25.40 \pm 4.22$ \\
$-20.60 \pm 740$
\end{tabular} & N S. & N S & N S \\
\hline All & $\begin{array}{l}0 \\
1 \\
2 \\
3 \\
1 \\
5\end{array}$ & $\begin{array}{l}88 \\
85 \\
69 \\
32 \\
19 \\
12\end{array}$ & $\begin{array}{l}5647 \pm 186 \\
17.11 \pm 1.48 * * * \\
45.99 \pm 178 * * * \\
46.81 \pm 2.46 * * * \\
45.32 \pm 2.89 \\
43.33 \pm 1.63\end{array}$ & $\begin{array}{r}- \\
-9.33 \pm 1.09 * * * \\
-10.12 \pm 1.41 * * * \\
-8.88 \pm 2.31 * * * \\
-5.16 \pm 2.50 \\
-617 \pm 3.14\end{array}$ & 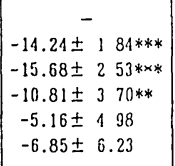 & $\begin{array}{r}32 \\
23 \\
16 \\
5 \\
5 \\
2\end{array}$ & $\begin{array}{l}19.53 \pm 215 \\
4152 \pm 1.68 * * * \\
40.38 \pm 339 * * * \\
4460 \pm 550 * \\
39.40 \pm 189 * * \\
11.00 \pm 5.00\end{array}$ & 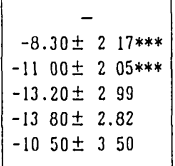 & $\begin{array}{l}- \\
-13.55 \pm 4.56 * * \\
-22.31 \pm 4.26 * * * \\
-22.63 \pm 4.87 \\
-25.40 \pm 4.22 \\
-2060 \pm 740\end{array}$ & $\begin{array}{l}* \\
* \\
\text { N S }\end{array}$ & N.S & $\begin{array}{l}\text { N S } \\
\text { N S }\end{array}$ \\
\hline
\end{tabular}




\section{3) プロブコール 5 年投与における LDL-C の変動}

プロブコール投与後の LDL-C の推移をみた (Table 3). 投与 1 年後 LDL-C は有意に低下し， 5 年間続いた. 1 年後の低下量は約 32〜35 mg/d $l$ で, 低下率は約 $13 \sim 17 \%$ であった，食前群と食後群で差はなく，単独群と併用群
でも有意差はなかった。

4) プロブコール 5 年投与における HDL-C の変動 プロブコールによる HDL-Cの変動をみた (Table 4). 食前群, 食後群ともに薬物投与 1 年後は有意に低下し, 5 年間続いた。低下量は平均 $9 \mathrm{mg} / \mathrm{d} l$ で，低下率は絇
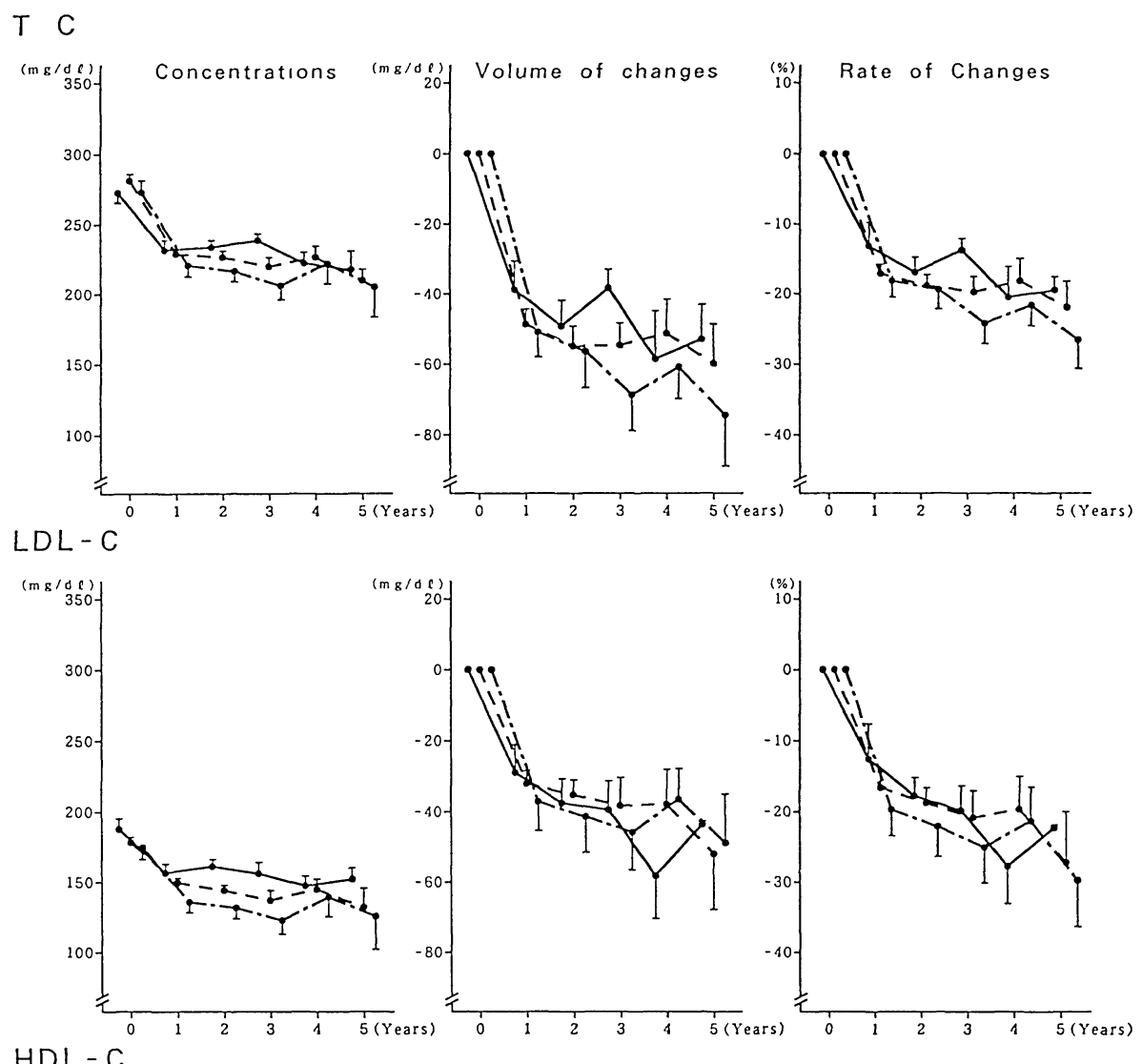

HDL - C
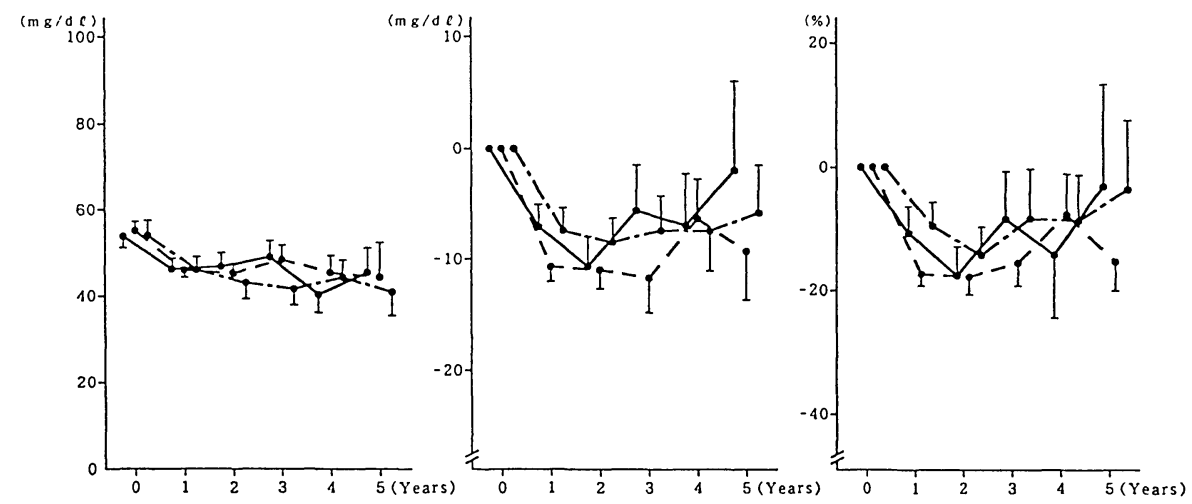

Fig. 1 Changes of the total cholesterol (top) LDL-cholesterol (middle) and HDL-cholesterol level (bottom) during treatment for 5 years with probucol by diabetic treatment with diet alone, sulfonylurea and insulin.

- D Diet alone $(\mathrm{n}=25)$

$\bullet-\cdots$ Sulfonylurea $(\mathrm{n}=63)$

-.- Insulin ( $\mathrm{n}=32)$

Values are expressed as the mean \pm S.E. 
$14 \%$ であった。 またパンテチン併用群においても HDL-C の低下は，プロブコール単独群と同程度にみと められ，両群間に有意差はなかった。

5) プロブコール 5 年投与における中性脂肪 (TG) の 変動

プロブコールの TG への影響を食前群 55 名で検討し た. 投与前 $\mathrm{TG}$ 值は $214.1 \pm 28.9 \mathrm{mg} / \mathrm{d} l(\mathrm{Mean} \pm$ S.E.), 1 年後 $153.9 \pm 16.6 \mathrm{mg} / \mathrm{d} l$ と低下したが, 推計学的に有 意差はみられなかった。また 2 年後以降 5 年後まで同様 で有意な変動はなかった。

6) 糖尿病治療法別にみたプロブコールの血中脂質へ の影響

糖尿病治療法別に食事療法, スルフォニール尿素凨, インスリン療法の 3 群にわけて観察した (Fig. 1). プロ ブコールの TC, LDL-C, HDL-C に対する低下作用は， これら 3 群間でいずれも有意に異なることはなかった.

7） HDL-C の層別分類におけるプロブコール投与の 血中脂質への影響

次にプロブコールによる HDL-C の低下が HDL-C 濃 度により差があるか否かを検討した (Fig. 2). ここでは 全例で，薬物投与前值の HDL-C が $70 \mathrm{mg} / \mathrm{d} l$ 以上（高
HDL-C 群), $69 \sim 41 \mathrm{mg} / \mathrm{d} l$ (正 HDL-C 群), $40 \mathrm{mg} / \mathrm{d} l$ 以 下 (低 HDL-C 群) の 3 群に層別して, プロブコール投与 後の HDL-C, TC, LDL-C の低下に差があるか否かをみ た. 高 HDL-C 群においては, HDL-C 前値 $81.52 \pm 1.98$ $\mathrm{mg} / \mathrm{d} l$ から 1 年後 $63.43 \pm 2.31 \mathrm{mg} / \mathrm{d} l$ と低下し, 低下量 は $18.10 \pm 2.22 \mathrm{mg} / \mathrm{d} l$, 低下率は $21.93 \pm 2.58 \%$ であった。 この低下は 3 年目まで有意であったが, その後は少数例 のため有意差はみられなかった，正 HDL-C 群では前值 が $52.87 \pm 0.88 \mathrm{mg} / \mathrm{d} l$ から 1 年後 $44.59 \pm 1.00 \mathrm{mg} / \mathrm{d} l$ と低 下し, 低下量 $8.38 \pm 1.00 \mathrm{mg} / \mathrm{d} l$, 低下率 $15.11 \pm 1.81 \%$ で あった。この低下は 2 年目以降もほぼ同様に持続した。 しかし低 HDL-C 群においては, 前值 $33.10 \pm 1.30 \mathrm{mg} / \mathrm{d} l$ で 1 年後も $31.71 \pm 1.67 \mathrm{mg} / \mathrm{d} l$ と有意な変動をみとめず, その後の 5 年間においてもかわらなかった. 一方 TC と LDL-C のプロブコール投与後の低下は，低 HDL-C 群 においても高 HDL-C 群や正 HDL-C 群とほぼ同程度 にみとめられ，かっ 5 年間持続した (Fig. 3).なお低 HDL-C 群 21 名の臨床的背景をみると, 既往に心筋梗 塞をもつもの 7 名, 糖尿病性腎症 5 名うち透析中の 2 名 が含まれた．経過中全例に副作用の出現や糖代謝の悪化 はみられず，また新たな脳・心血管障害の併発もみられ

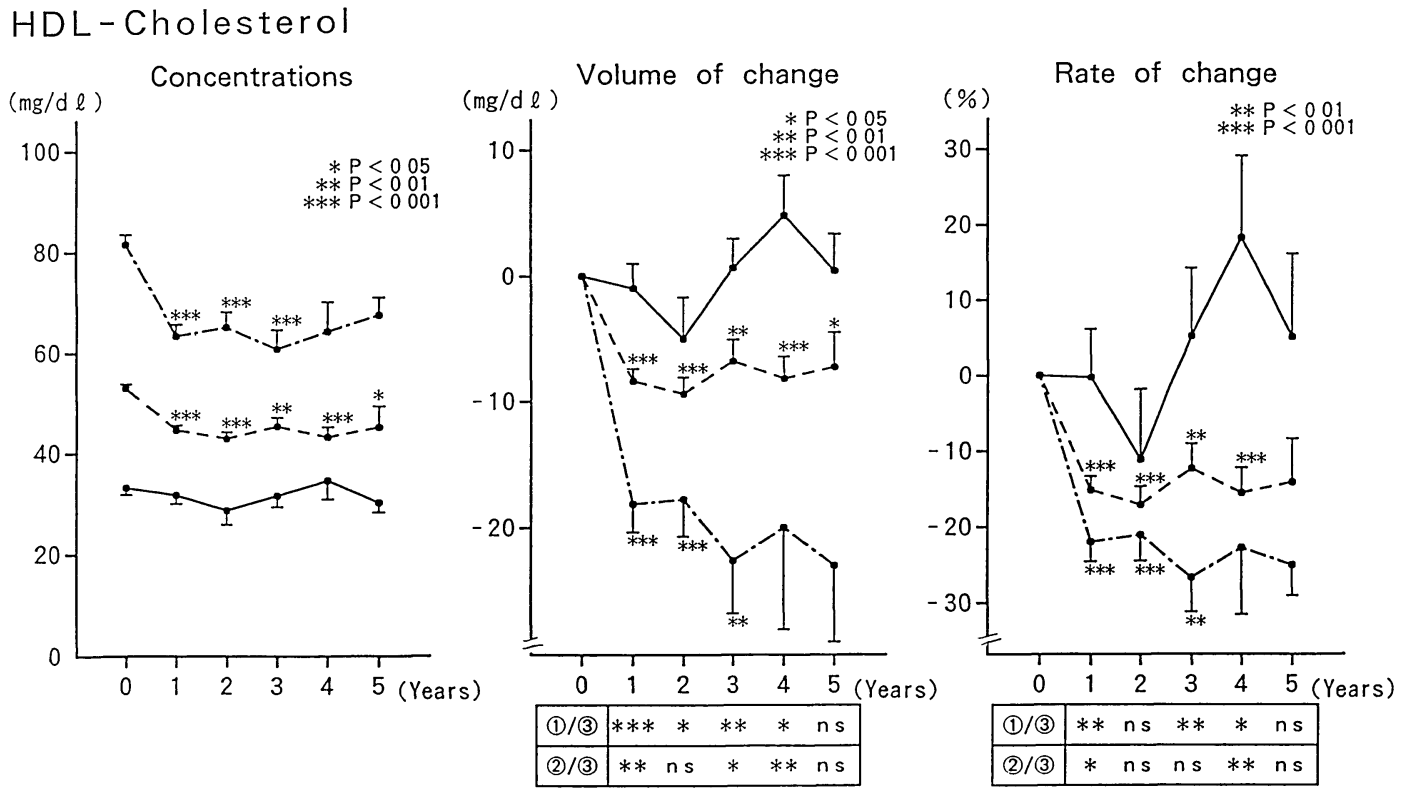

Fig. 2 Comparison of the changes of HDL-C in the three groups set on the basis of pretreatment HDL-cholesterol levels.

(1) - - Pretreatment HDL-C $\geq 70 \mathrm{mg} / \mathrm{d} l . \quad(\mathrm{n}=21)$

(2) - - Pretreatment HDL-C $=41-69 \mathrm{mg} / \mathrm{d} l . \quad(\mathrm{n}=78)$

(3) Pretreatment HDL-C $\leq 40 \mathrm{mg} / \mathrm{d} l . \quad(\mathrm{n}=21)$

Values are expressed as the mean \pm S.E.

Levels in each years vs. the initial value: ${ }^{*} \mathrm{p}<0.05, * * \mathrm{p}<0.01, * * * \mathrm{p}<0.001$

The significant differences (1) and (3), and (2) and (3) are shown in the table below. 
T C

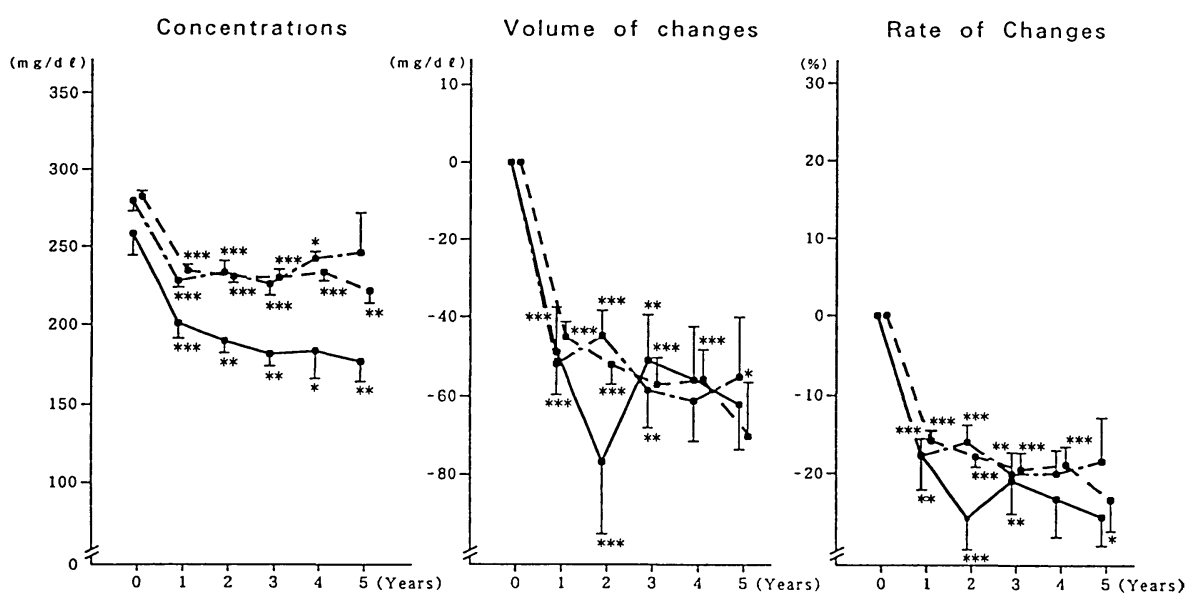

LDL- C
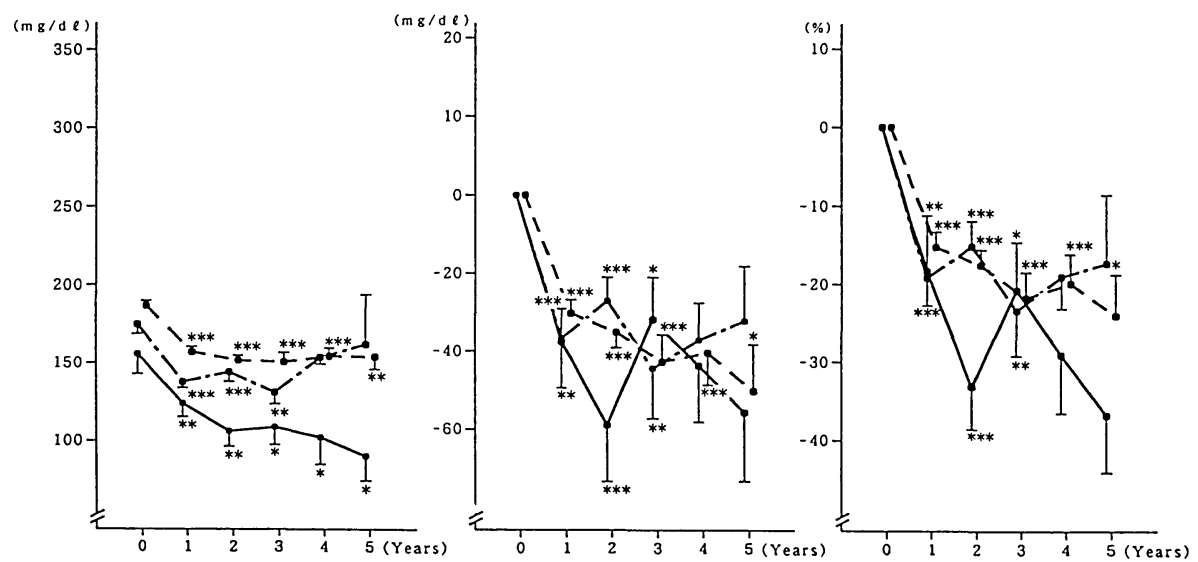

Fig. 3 Comparison of the changes of total cholesterol and LDL-cholesterol in the three groups set on the basis of pretreatment HDL-cholesterol levels.

(1) - -.- Pretreatment HDL-C $\geq 70 \mathrm{mg} / \mathrm{d} l . \quad(\mathrm{n}=21)$

(2) - $-\cdots$ Pretreatment HDL-C $=41-69 \mathrm{mg} / \mathrm{d} l .(\mathrm{n}=78)$

(3) - Pretreatment HDL-C $\leq 40 \mathrm{mg} / \mathrm{dl} . \quad(\mathrm{n}=21)$

Values are expressed as the mean \pm S.E.

Levels in each years vs. the initial value: ${ }^{*} \mathrm{p}<0.05,{ }^{* *} \mathrm{p}<0.01,{ }^{* * *} \mathrm{p}<0.001$

なかった.

\section{IV. 考 察}

日本におけるプロブコールの臨床使用は 1985 年から 始まり, 現在までに 5 年以上経過した。当初は, プロブ コールが総コレステロールや LDL-C を強力に低下させ るとともに，HDL-C をも低下させるという報告が多か った ${ }^{3 \sim 5)}$. しかしその多くは家族性高 TC 血症が対象で, 使用期間も比較的短期間であった。本報は NIDDM の みを対象としていることや，使用期間が 5 年間と長期に
わたったことが既報と異なる点である．TC p LDL-C の低下量はプロブコールの投与量に依存するといわれる が，われわれの成績では 1 日 $500 \mathrm{mg}$ 投与で約 $17 \%$ の 低下であった。この值は秦らの全国規模で行われた調查 成績6) と一致した. HDL-C の低下についてはプロブコ ールにパンテチンを併用すると緩徐になると報告された が，われわれの検討では単独群と併用群で有意差がみら れなかった. TGについては彼らはプロブコール投与後 軽度の低下をみとめているが，本論文では有意な変動が みとめられなかった。 また，糖尿病治療法によりコレス 
テロール低下作用に差があるか否かを検討したが，治療 法により異なることはなかった。したがってプロブコー ルのコレステロール低下作用に，血糖コントロールの直 接関与はないものと推測された.

プロブコールが HDL-C を低下させる機序については 未だ明確でない．経口投与されたプロブコールは小腸で カイロミクロンに取り込まれた後肝へ転送される. 肝で はVLDL 中に入り血中へ放出され，経時的に HDL 分 画や LDL 分画に取り込まれていることが推測されてい る7)。 また長期投与では LDL 分画中に高濃度に長時間 存在することが確認されている ${ }^{8)}$. 最近 Bagdade ら ${ }^{9)}$ は, プロブコールが HDL から VLDL や LDL のコレス テロールエステル転送蛋白 (CETP) 活性を増加させたと

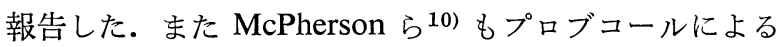
CETP 活性の増加をみとめ，これが HDL の低下をもた らす可能性を示した. これらの論文より，プロブコール は HDL 代謝を促進し，その結果 HDL よりコレステロ 一ルが失われていくものと推測される.

臨床的にみて，プロブコール投与による HDL-C 低下 作用は一様ではなく，HDL-C 前值の高いものほど低下 が大であり，低いものではそれ以上有意な低下をきたさ なかった. HDL-C 前值が低いものに対するプロブコー ル投与の影響をみた過去のいくつかの論文によれば，い ずれも問題ないとしている.すなわち，Risen ら ${ }^{11)}$ は原 発性高 TC 血症で HDL-C 前值が平均 $37 \mathrm{mg} / \mathrm{d} l$ のもの にプロブコール 1 日 $1,000 \mathrm{mg}$ を投与したが, その後の HDL-C (不変であった。泉ら ${ }^{12)}$ は糖尿病を含むIIa， IIb 型高脂血症にプロブコールを 1 日 $750 \mathrm{mg} 2$ 年間投 与したところ, 前值が $40 \mathrm{mg} / \mathrm{d} l$ 未満群の HDL-C は有 意に低下しなかったとのべている。また渕本ら ${ }^{13)}$ も同 様に II 型高リポ蛋白血症にプロブコール $500 \mathrm{mg}$ を 16 週間投与しても, HDL-C $40 \mathrm{mg} / \mathrm{d} l$ 未満群においては有 意な低下をみとめなかったと報告している，本報では対 象がすべて NIDDM であったが, やはり前值が $40 \mathrm{mg} / \mathrm{d} l$ 以下のものでは，プロブコール $500 \mathrm{mg}$ 使用後も有意な 低下をみることなく，5年間継続できた．このようにプ ロブコールによる HDL-C の低下作用が， ある一定值以 下の場合にはそれ以上さがらないように調節されている ことがわかったが，その機構については不明である。お そらくリポ蛋白相互間のコレステロール輸送がプロブコ ールにより調節されているのかもしれない。

近年，プロブコールによる HDL-C 低下率がアキレス 腱黄色腫の退縮率と有意に正相関することが報告 ${ }^{14)} さ$ れて以来, プロブコールの HDL-C 低下作用が見直され るようになった。 またプロブコールには, LDL の酸化 変性を抑制して粥状動脈硬化病巣の進展を抑制する ${ }^{15)}$,
など画期的な報告がみられるＮIDDM に高 TC 血症が 合併すれば冠動脈硬化症の危険因子が増加するので，早 期より抗脂血剤の使用が必要となる．プロブコールは， 低 HDL-C 血症を伴いやすい NIDDM に扔いても，動 脈硬化の予防と治療に有用な薬剤と思われる。

\section{V. 結 論}

高 TC 血症を合併した NIDDM に，プロブコール 250 500 mg/日を 5 年間使用して，次の結果を得た。

1) $\mathrm{TC}$ は 1 年後低下量 $45 \mathrm{mg} / \mathrm{d} l$, 低下率 $17 \%$ で, 5 年間 持続した。 2) LDL-C は 1 年後低下量 $32 \mathrm{mg} / \mathrm{d} l$, 低下率 $17 \%$ で，5年間持続した．3) 糖尿病治療法別に食事，ス ルフォニール尿素剤, インスリンの 3 群にわけてみても, プロブコールの TC, LDL-C, HDL-C の低下量や低下率 に差はなかった４）HDL-C が高值の群ほどプロブコー ルによる低下が大であった。一方， HDL-C が $40 \mathrm{mg} / \mathrm{d} l$ 以下の群では，プロブュール使用後の有意な低下はみら れなかったが，TC と LDL-C は有意に低下した。 5) 観 察期間中に新たな動脈硬化疾患の発症はなく，特記すべ き副作用もなかった．以上より NIDDMにおける高 TC 血症に対して，プロブコール長期使用の有用性がみとめ られた。

本論文の要旨は第 23 回日本動脈硬化学会総会で発表 した.

\section{文献}

1) Howard, B. V., Savage, P. J., Bennion, J. and Bennett, P. H.: Lipoprotein Composition in diabetes mellitus. Atherosclerosis, 30: 153-162 (1978).

2) Stern, M. P. and Haffner, S. M.: Dyslipidemia in type II diabetes. Implications for therapeutic intervention. Diabetes Care, 14: 1144-1159 (1991).

3) 和田成雄, 中山昌彦, 正木清孝, 水谷孝昭, 礒田次 雄, 和田 勝, 小関忠尚, 大塚昭男, 村中日出男, 森 本昌親，野村 博，土井久人，山本 寿，松岡 慧， 中野 裕, 高島昭佳, 河野 剛, 大迫文榣, 斉藤 曻, 岩崎良文, 赤沢好温, 大石まり子, 青地 脩,

森 邦子, 大川原康夫, 豊田栄一, 村上正志, 橋田 悦, 岡本博史, 福井 豲, 荻野耕一: 高脂質血症患 者に対するプロブコールの効果. 動脈硬化, 10: 1133-1142 (1983).

4) 岡本良三, 高野新二, 築谷 学, 末広厚夫, 羽溪 眞, 藤野基博, 福崎 恒, 吉田 睦, 初村利衛, 堀 康 郎, 廣内 恒, 今井直昭, 太田耕治：血清脂質值に 対する Probucol の効果. 動脈硬化， 10: 1125-1131 (1983).

5) 葛谷文男, 吉峯 徳, 大原清仁, 篠田 功, 木村 裕, 鈴木 茂, 船越宏洸, 安藤 㦑, 小林由樹, 金優, 下村尚一, 大井美栄子, 東浦 宗, 角田博信, 篠田 
廣：高脂質血症患者に対するプロブコーッの効果. 動脈硬化, 10: 1151-1156 (1983).

6) 秦 暞哉, 板倉弘重, 斉藤 康, 五島雄一郎, 後藤 由夫, 八杉忠男, 葛谷文男, 藤浪隆夫, 熊谷 朗, 山本 章, 梶山梧朗, 国府達郎, 荒川規矩男, 飯村 攻，小野寺庚午，金沢武道，丸浜喜亮，立木 楷， 及川真一，大平誠一，阿部隆三，笠原浩一郎，家入 蒼生夫, 中村保子, 高橋壮一郎, 水野 學, 大竹 稔, 赫 彰郎, 福生吉裕, 村勢敏郎, 沼野藤夫, 勝沼英 宇，河原玲子，池田義雄，白井厚治，玉地寛光，本 間康彦, 清瀬 闊, 佐々木憲裕, 森 皎祐, 金山正 明, 濱崎智仁, 馬㴊 宏, 村上暎二, 中井継彦, 清 島 満, 吉峯 徳, 佐久間長彦, 普天間新生, 板津英 孝，繁田幸男，原納 優，日高秀樹，西 重生，金 綱隆弘，鉄谷多美子，関 一郎，西沢良記，松沢佑 次, 山下静也, 石川兵衛, 湯川 進, 宮井利彦, 石 川雄一，鍋島健治，奥野巍一，富長將人，和田一成， 石川勝憲, 三木茂裕, 後東俊博, 斉藤 昇, 未廣 正, 古賀俊逸, 佐々木淳, 上田正人, 野原正敏, 長淿重 信，弱澤春生，田中弘充，有馬新一，三村悟郎，菊 池 裕, 山田賢典, 田中恒男: Probucol·Pantethine 併用による血清脂質およびリポ蛋白, アポ蛋白に対 する効果. Therapeutic Research, 5: 315-363 (1986).

7) 竹越敏夫, 須藤賢一, 稡川馨子, 秦 臀哉, コレス テロール低下薬 Probucol のヒト血清リポ蛋白分画 への分布に関する検討. 動脈硬化， 10: 1113-1117 (1983).

8）加々美明彦, 近藤和雄, 宮島恵美子, 多田紀夫, 石 川俊次, 中村治雄, 森田誠治, 蒔田信也: Probucol の臨床薬理学的研究 (その 2)-Probucol の血漿リ ポ蛋白内転送に関する研究——動脈硬化，10: 1107-1111 (1983).

9) Bagdade, J. D., Kaufman, D., Ritter, M. C. and
Subbaiah, P. V.: Probucol treatment in hypercholesterolemic patients: Effects on lipoprotein composition, HDL particle size and cholesteryl ester transfer. Atherosclerosis, 84: 145-154 (1990).

10) McPherson, R., Hogue, M., Milne, R. W., Tall, A. R. and Marcel, Y. L.: Increase in plasma cholesteryl ester transfer protein during probucol treatment. Relation to changes in high density lipoprotein composition. Arterioscler. Thromb., 11: 476-481 (1991).

11) Riesen, W. F., Keffer, M. and Mordasini, R.: Probucol in hypercholesterolemia. A double blind study. Atherosclerosis, 36: 201-207 (1980).

12）泉 寛治, 中田良和，小出玲三，下村 惇，大原道 之, 杉岡五朗, 宇野伝治, 南川 豊, 新実光朗, 赤 澤好温, 大石まり子，野間靖涁，伊東靖夫，原口義 邦：高脂血症患者に対する Probucol の長期使用経 験. 動脈硬化, 12: 973-984 (1984).

13）㴊本武文, 正路浩二郎, 上原偉男, 桶口好美, 清水 能人, 三島康男，木畑正義：II 型高リポ蛋白血症患 者におけるProbucol (500 mg 1 日) 投与の影響. 動 脈硬化, 12: 965-971 (1984).

14) Yamamoto, A., Matsuzawa, Y., Yokoyama, S., Funahashi, T., Yamamura, T. and Kishino, B.: Effects of probucol on xanthomata regression in familial hypercholesterolemia. Am. J. Cardiol., 57: 29H-35H (1986).

15) Kita, T., Nagano, Y., Yokode, M., Ishii, K., Kume, N., Ooshima, A., Yoshida, H. and Kawai, C.: Probucol prevents the progression of atherosclerosis in Watanabe heritable hyperlipidemic rabbit, an animal model for familial hypercholesterolemia. Proc. Natl. Acad. Sci. U.S.A., 84: 5928-5931 (1987). 


\title{
Summary
}

\section{Effect of Probucol Therapy for Five Years on HDL-Cholesterol Levels in Non-Insulin Dependent Diabetic Patients with Hypercholesterolemia}

\author{
Reiko Kawahara, Naomi Shibata, Satomi Shibasaki, Teiko Amemiya, \\ Rieko Totani, Munehiro MiYamae, Kazuo Sasamoto and Yasue OMORI \\ Diabetes Center, Tokyo Women's Medical College
}

Probucol (250-500 mg/day) was administered for five years to treat hypercholesterolemia in noninsulin dependent diabetes mellitus (NIDDM). Changes in total cholesterol, LDL-cholesterol and HDL-cholesterol levels were investigated in 120 diabetic patients ( 29 males and 91 females, aged between 30 and 83 years). The following results were obtained:

(1) The total-cholesterol level decreased by $45 \mathrm{mg} / \mathrm{d} l(17 \%)$ after one year of probucol treatment and the decreased level was maintained subsequently for five years.

(2) The LDL-cholesterol level decreased by $32 \mathrm{mg} / \mathrm{d} l(17 \%)$ after one year of probucol treatment and this decreased level was maintained subsequently for five years.

(3) Among the groups receiving only a dietary, sulfonylureas, or insulin treatment, there were no significant differences in the effects of the treatment with probucol on the serum TC, LDL-C, and HDL$\mathrm{C}$ levels over a five-year period.

(4) In patients with an HDL-cholesterol level $\leq 40 \mathrm{mg} / \mathrm{d} l$, there was no significant decrease in the HDL-cholesterol level, although the total- and LDLcholesterol levels were significantly decreased.

(5) No episodes of arteriosclerotic disease were newly reported during the study period. There were also no reports of adverse reactions requiring the discontinuation of probucol treatment.

These findings suggest that probucol is useful for the long-term treatment of hypercholesterolemia in NIDDM.

Key words: probucol, HDL-cholesterol, LDLcholesterol, non-insulin dependent diabetes mellitus (NIDDM), hypercholesterolemia. 